\title{
The development of democratic society and spiritual renewal in the views of eastern and western thinkers
}

\section{Turdiev BEKHRUZ ${ }^{1}$}

Researcher of Bukhara State University,

\section{ARTICLE INFO \\ Article history: \\ Received September 2020 \\ Received in revised form \\ 15 September 2020 \\ Accepted 25 September \\ 2020 \\ Available online \\ 1 October 2020}

\section{Keywords:}

Heritage

Spirituality

Philosophy

Civilization

Zoroastrianism,

"Aphorisms"

Moral

Customs

social progress

civil society

enlightenment

Freedom

\begin{abstract}
Today, without an in-depth and comprehensive analysis of various ideas and views on spiritual renewal in the development of society, without drawing appropriate conclusions and lessons from them, we can not move from national revival to the greatest goal of national revival. This article deeply examines the scientific and philosophical views of great thinkers - our forefathers, scholars and public figures of different periods on the spiritual development of society.
\end{abstract}

2181-1415/C 2020 in Science LLC.

This is an open access article under the Attribution 4.0 International (CC BY 4.0) license (https://creativecommons.org/licenses/by/4.0/deed.ru)

\section{Демократик жамиятнинг ривожланиши ва маънавий янгиланиш шарқи ва ғарбий муфофкаларнинг кўришида}

\section{Калит Сўзлар: \\ Мерос \\ Маънавият \\ Фалсафа, \\ Цвилизация \\ Зардуштийлик \\ "Афоризмлар"}

\section{АННОТАЦИЯ}

Жамият тараққиётида маънавий янгиланишлар тўғрисидаги турли ғоя ва мавжуд бўлган қарашларни чуқур ва атрофлича тахлил этмай, улардан тегишлича хулоса ва сабоқ чиқармай туриб, миллий тикланишдан миллий юксалиш улуғ мақсад сари бора олмаймиз. Ушбу мақолада турли даврдаги буюк мутафаккир- аждодларимиз, аллома

\footnotetext{
${ }^{1}$ Researcher of Bukhara State University, Uzbekistan, Bukhara city e-mail: bekiuz@mail.ru
} 
Ахлоқ

Урф-Одатлар

Фуқаролик Жамияти

Маърифат

Эркинлик ва жамоат арбобларининг жамиятнинг маънавий

ривожлвниш хақидаги илмий-фалсафий қарашлари чуқур тадқиқ этилган.

\section{Развитие демократического общества и духовное обновление в взглядах восточных и западных мыслителей}

Ключевые-слова:
Наследие
Духовность
Философия
Цивилизация
Зороастризм
“Афоризмы”
Нравственность
Обычаи
Традиции
Гражданское общество
просвещение
Свобода.

\section{Ключевые-слова:}

Наследие

Духовность

Философия

Цивилизация

Обычаи

Традиции

просвещен

\begin{abstract}
АННОТАЦИЯ
Не проанализировав идеи и взгляды о духовном обновлении имеющих значение в развитие общества, не сделав для себя выводов, мы не сможем достичь такой цели как “От национального возрождения к национальному прогрессу”. В данной статье анализируются научнофилософские взгляды великих мыслителей-наших предков, учёных и общественных деятелей живших в различные исторические периоды.
\end{abstract}

\section{INTRODUCTION}

Spiritual renewals are the historical and philosophical process associated with the objective assessment, understanding and rational use and development of the people's past, cultural and spiritual heritage, national and universal values. In this process, if the people are unaware of their history, national culture, values, spiritual heritage, there will be no clear vision of the past, no specific strategic goal for the future, no desire to mobilize on this path to unity. It can be seen that the process of spiritual renewal of society and people is inextricably linked with each other. This means that the social, economic and political development of a society is impossible without certain spiritual factors.

In our opinion, the renewal of national spirituality has also contributed to the development of relations between peoples. The nation, which understood itself justly, was valued by other nations as well, and tried to strengthen equal, friendly relations with them. For this reason, the wise thinkers and famous scholars of the people in their efforts to raise the national spirituality have recognized that respect for other peoples, the establishment of friendly relations with them is an important spiritual factor in the development of the country.

The philosophical heritage of the peoples of Central Asia has made a significant contribution to the history of world philosophy. The philosophy of these peoples is distinguished not by such antiquity as the philosophy of ancient India, China, Egypt, Greece, but by the evolution of philosophical and religious ideas that have strongly influenced the spirituality of peoples of the world in their development.

\section{MATERIALS AND METHODS}

In writing this article, the methods of comparative analysis, generalization, comparison, analysis, synthesis, historical, correlation of knowledge were used. The article also relied on the principles of objectivity and systematicity.Therefore, it is expedient to 
conduct a scientific analysis of the role of spiritual renewal in the development of society on the basis of examples from the works of ancient Eastern and Western philosophers. No wonder the East has long been described as the center of spirituality and civilization.

The philosophers of the ancient East put forward many unique ideas in the concepts of spiritual growth, self-awareness and perfection, especially in the philosophy of Zoroastrianism, Buddhism, Confucianism.

\section{DISCUSSION AND RESULTS}

The noble ideas of the ancient Zoroastrian philosophy of peoples of Central Asia play a special role in the spiritual development of society. It embodies the spirituality, culture, customs and traditions, moral values of the ancient peoples of Central Asia. It promotes the ideas of peace and stability, which serve the spiritual revival of society, and the perfection of human beings in honest work with one another. In Zoroastrian philosophy, "Those who want light for others will have light. In the light of truth, bestow upon us Your enlightenment from the Good Intentions, so that we may enjoy every moment, every hour, every day of our lives"[1. -P.52] or "It is necessary to strive for the prosperity of the world, to preserve it with kindness and to bring it to light" [1. -P.120] such ideas have not lost their relevance today. The values associated with Zoroastrian ideas, which in his time played an important role in encouraging the people to the ideas of goodness and justice, the formation of living traditions, the development of agriculture and urban culture, still play a significant role in defining the peculiarities of our people's way of life.

The views of Confucius (551-479) have a special place in the history of sociophilosophical thought in ancient China. The philosopher made a great contribution to the development of socio-philosophical thought in ancient China. His "Aphorisms" are an integral part of the spirituality of the peoples of the world. In his philosophical views, he argues that every member of society is involved in spiritual renewal, that human life depends on destiny, and that if a person strives for noble goals, he will surely be blessed with wealth and glory. In his philosophical views, he argues that each member of society is involved in spiritual renewal, that human life depends on destiny, and that if a person strives for noble goals, he will surely be blessed with wealth and glory.

In the philosophical views of the Confucius, moral issues occupy a central place. Confucius, relying on the customs, rituals and teachings of the ancient ancestors, said that the fame of the ancestors raises their descendants, the true foundation of society, the need to restore and follow ancient customs, rituals, traditions to further strengthen the foundation [2. -P.9].

Today, the expediency of the teachings created by Confucius can be seen in the spiritual and enlightenment reforms in our country on the restoration of ancient customs, traditions, national ceremonies and holidays, the historical memory of our ancestors. Although the first socio-philosophical ideas in human civilization first originated in the East, they have literally reached their peak in the West, especially in Ancient Greece and Rome. Socio-philosophical ideas in ancient Greece stand out in this regard. Representatives of the philosophical school founded by Socrates, Plato, and Aristotle in ancient Greece, their views on the spiritual renewal of society served not only in the West but also in the rise of Eastern philosophy. 
Socrates (469-399 BC) was one of the philosophers who drastically changed the development of philosophy, despite the fact that he was an irrational man in Greek philosophy and did not write anything during his lifetime.

The being called human, is somehow not what it is but what it should be, not a completion but volition, not a success reached but a promise, an attempt. This desire for self-realization and self-completion is the essence of human being (Versenyi, 2007: 135136). However, in order to release this potential power he needs to be enlightened by the instructive light of knowledge. In this context, according to Socrates, education helps the seeds of good will grow inside human.

Socrates tells that: "If to me as I am the son of a midwife and that I understand the art of midwifery, and try to give the best answer possible to my questions. My art of midwifery is in general like theirs; the only difference is that my patients are men, not women, and my concern is not with the body but with the soul that is in travail of birth" [3. -P.4485]. In this context, the task of the educator according to Socrates is not conveying knowledge to the learner but disclosing the existing internal knowledge. According to Socrates knowledge is attained not through conveying knowledge but through research and this research lasts for the life. Keeping in our minds that Socrates calls himself not a wise man but a philosopher, it should be noted that the pursuit of knowledge and the search for knowledge is a lifelong process.

The great scientist, philosopher, and art historian who left an indelible mark on the history of world philosophy was Plato (428/427 or 424/423 BC - 348/347 BC). Plato's teachings on society and the state are central to his worldview. Plato's teachings on society and the state are central to his worldview. Plato wrote works on socio-political issues called "State", "Laws", "Politics" and "Republic".

In his work "Republic", where Plato offers a theory about how art affects the soul and forms character in ways that people are often not aware of. If you are designing an ideal society, as Plato does in the Republic, and contrasting it with the corruptions of existing societies, as he also does in the Republic, then you need to think about much more than political institutions in a narrow sense. You need to think about all the influences, all the ideas, images, and practices, that make up the culture of a society [4. -P.217].

On the basis of Plato's dream about an ideal state lies the idea of Justice. According to Plato, the obedience of all members of society to the laws of a just society is the main guarantee of social progress. According to Plato, the obedience of all members of society to the laws of a just society is the main guarantee of social progress.

Aristotle (384-322 BC) was a great philosopher who amazed the world with his encyclopedic heritage and was recognized in the East as the "First Master" for his scientific and philosophical ideas. Aristotle's views on the rise of society stand at the center of the doctrine of the scientist. The philosopher's views on the development and progress of society are analyzed in such works as "State", "Rhetoric", "Politics", "Physics".

The philosopher writes in "A Treatise on Government": Since in every art and science the end aimed at is always good, so particularly in this, which is the most excellent of all, the founding of civil society, the good wherein aimed at is justice; for it is this which is for the benefit of all. Now, it is the common opinion, that justice is a certain equality; and in this point all the philosophers are agreed when they treat of morals: for they say what is just, and to whom; and that equals ought to receive equal: but we should know how we are 
to determine what things are equal and what unequal; and in this there is some difficulty, which calls for the philosophy of the politician[5. -P.127].

Therefore, different political systems replace each other and new ones emerge. Even if the state changes, the people will not change, they will remain the same, only the form of government will change: Everything comes into being for the sake of an end. An end is that which always appears as the final result of a development, in accordance with natural law and by a continuous process, and in which the process attains its completion. Thus in the process of becoming the mental is later than the physical, and in the mental realm the intellectual element in its pure form is again the later [6. - P.75].

However, the goal of the human community should not only be to live, but to be higher, that is, to live happily, so the goal of the state is to create a happy life. Thus, the task and goal of the state is to create a happy life for families and many generations: "Chance and what results from chance are appropriate to agents that are capable of good fortune and of moral action generally. Therefore necessarily chance is in the sphere of moral actions. This is indicated by the fact that good fortune is thought to be the same, or nearly the same, as happiness, and happiness to be a kind of moral action, since it is well-doing" [7. -P.28].

Aristotle said that justice is a common happiness, but it must conform to the just parts of the common good: We may define happiness as prosperity combined with virtue; or as independence of life; or as the secure enjoyment of the maximum of pleasure; or as a good condition of property and body, together with the power of guarding one's property and body and making use of them. That happiness is one or more of these things, pretty well everybody agrees. From this definition of happiness it follows that its constituent parts are: good birth, plenty of friends, good friends, wealth, good children, plenty of children, a happy old age, also such bodily excellences as health, beauty, strength, large stature, athletic powers, together with fame, honor, good luck, and virtue. A man cannot fail to be completely independent if he possesses these internal and these external goods; for besides these there are no others to have (Goods of the soul and of the body are internal. Good birth, friends, money, and honor are external). Further, we think that he should possess resources and luck, in order to make his life really secure. As we have already ascertained what happiness in general is, so now let us try to ascertain what of these parts of it is [8. - P.19-20].

Based on the above, it should be noted that in the socio-philosophical views of ancient Eastern and Western thinkers, the issues of the spiritual uplift of society and man are leading. The masterpieces of spiritual heritage by great thinkers and philosophers are remarkable today, as they appeal to the whole of humanity.

The $18^{\text {th }}$ century was a period of renewal of Enlightenment in the history of world philosophy. The spiritual and enlightenment views of such enlighteners as John Locke[9.P.3115], David Hume [10.-P.483], Voltaire [11.-P.173], Jean-Jacques Rousseau [12.P.636], Ch.L.Montesquieu [13.-P.706] were of great importance in the development of European enlightenment ideas.

John Locke (1632-1704) was an English philosopher and the founder of liberalism. Locke's ideas played a major role in the history of European philosophical and sociopolitical thought. He outlines a new theory of mindcontending that the gentleman's mind was a tabula rasa or "blank slate"; containing no innate ideas. The treatise explains how to educate that mind using three distinct methods: the development of a healthy body; the 
formation of a virtuous character; and the choice of an appropriate academic curriculum. Locke attempts to popularise several strands of seventeenth century educational reform as well as introduce his own philosophical ideas on education [14. -P.1408].

David Hume (1711-1776) - English philosopher, historian, economist. Describes the basic principles of ideas: "For when men, from their early education in society, have become sensible of the infinite advantages that result from it, and have besides acquired a new affection to company and conversation; and when they have observed, that the principal disturbance in society arises from those goods, which we call external, and from their looseness and easy transition from one person to another" [15. -P.489].

Voltaire (1694-1778) was a French writer, philosopher and historian.Voltaire found inspiration in their ideals of a free and liberal society, along with freedom of religion and free commerce. It thus becomes clear that luxury is identified with the entirety of Voltaire's "Enlightenment project". It is seen as integral to the progress of reason, religious tolerance, moderate government, justice, politeness, increased sociability, and the arts and sciences. It is in fact the visible proof of the ideal of human community: the development of human potential and human happiness or pleasure. Hence Voltaire's own persona became strongly bound up with luxury [16].

Jean-Jacques Rousseau (1712-1778) was a French philosopher, writer, and composer. Rousseau admits that in a corrupt society (such as the one in which he lived) only science, and even general enlightenment, can provide man with a measure of relief. In a society where it is no longer necessary or desirable that any prejudices be respected, one may freely discuss the sacred foundations of society and freely seek not merely for remedies of the prevailing abuses, but for what would be simply the best solution to the political problem [17. -P.16]. Under such conditions the direct and scientific presentation of that solution would at its worst be an innocent pastime; but assuming that there is a prospect of a revolution, the new political science might prepare public opinion not merely for the restoration of a healthy society, but for the establishment of a more perfect society than ever existed before.

The famous French writer, lawyer and philosopher Charles Louis de Montesquieu (1689-1755). It is in endeavouring to instruct mankind that we are best able to practise that general virtue which comprehends the love of all. Man, that flexible being, conforming in society to the thoughts and impressions of others, is equally capable of knowing his own nature, whenever it is laid open to his view; and of losing the very sense of it, when this idea is banished from his mind [18. -P.16].

The philosopher says the following about education: "Most of the book is devoted to moral education in republics. Montesquieu here is no liberal, but adopts instead Aristotle's teaching that the state ought to ensure that all citizens be inspired by the same passion, that prerequisite for the maintenance of the state. In a republic, this is the love of patrie and its laws, the persisting preference for the public over the private good. Because every citizen participates in the government, he must be possessed of the passion that will preserve it" [19. -P.79].

\section{CONCLUSION}

So, our thoughts on spiritual renewal, discussed above, have become an integral part of the history of spiritual revival not only in Central Asia but also in the peoples of the world. These ideas have been formed and developed in the process of studying the social 
environment, human relations, knowing the existing world and constantly striving to change it, and serve to promote the scientific thinking of nations, spiritual growth, advancement and implementation of ideas about human future. There is also a commonality in the works of thinkers of East and West in their views on the role of culture and enlightenment in the development of society. This can be seen through a variety of ideas and perspectives. That is, we see in them that the issue of enlightenment in the development of society, the role of education and its renewal, the acquisition of world knowledge is the main issue in the idea of these enlighteners. That is, it is emphasized that progress cannot be achieved without the development of enlightenment. In general, it can be seen that the ideas and views related to the democratic development of society have been the main dream of great thinkers and scholars in the history of mankind. There is no doubt that in today's conditions of independence, special attention is paid to achieving it in loyalty to the cultural heritage and traditions, which will serve human civilization.

\section{REFERENCES}

1. Jurayev N. Avesto: a historical and literary monument. -T., Creative publishing house named after Gafur Gulam, 2015. -P.52-120.

2. Confucius. Wisdoms. -T., Publishing House of the National Library of Uzbekistan named after Alisher Navoi, 2010. -P.9.

3. Fatih Demirci. Socrates: the prophet of life-long learning. //Procedia - Social and Behavioral Sciences , 2012, № 46. -P.4485.

4. Burnyeat M.F. Culture and Society in Plato's Republic. Harvard University, 1997. P.217.

5. Aristotle. A Treatrise on Government (Translator: William Ellis, A.M.). London, T. Payne, 1776 and J.M.Dent \& Sons Ltd., 2017. -P.127.

6. Werner Jaeger. Aristotle fundamentals of the history of his development. Great Britain. Oxford University press, 1962. -P.75.

7. Aristotle. Physics(Edited by Jonathan Barnes). New Jersey, Princeton University Press, Princeton, 1991. -P.28.

8. Aristotle. Rhetoric(Translated by W. Rhys Roberts). USA, Dover Publications, 2012. -P.19-20.

9. Complete Works of John Locke. United Kingdom, Delphi Classics, 2017. -P.3115.

10. The philosophical works of David Hume. Volume IV. Edited by T.H.Green, T.H.Grose. London, Longmans, Green and Co. 1875. -P.483.

11. Voltaire. Candide. Boni \& Liveright. USA, New-York, “The modern library”, 1918. -P.173.

12. Jean-Jacques Rousseau. The Confessions. By Angela Scholar. Edted by Patrick Coleman. USA, New-York, Oxford University Press, 2000. -P.636.

13. Montesquieu. The Spirit of the Laws. Translated and edited by Anne M., Cohler, Basia C., Miller, Harold Stone. USA, New-York, Cambridge University Press, 1989. -P.706.

14. Complete Works of John Locke. United Kingdom, Delphi Classics, 2017. -P.1408.

15. David Hume. A Treatise of Human Nature. Edited by L.A.Selby-Bigge. London, Oxford, Clarendon Press, 1839. -P.489.

16. Felicia Gottmann. The Eighteenth-Century Luxury Debate: The Case of Voltaire. The Eighteenth-Century Luxury Debate: The Case of Voltaire Thesis submitted for the degree of Doctor of Philosophy. University of Oxford, September 2010. -P.7. 
//https://ora.ox.ac.uk/objects/uuid:f5cdc51e-0ac1-4e01-8f7f-

3d47ab07e233/download_file?safe_filename $=$ Gottmann_thesis.pdf\&file_format=applicat ion\%2Fpdf\&type_of_work=Thesis

17. Jean-Jacques Rousseau: Human nature and history. Edted by John T.Scott. USA, New-York, Routledge Taylor \& Francis Group, 2006.-P.16.

18. Montesquieu, The Spirit of Laws (Thomas Nugent). Kitchener, Ontario, 2001. P.16.

19. Melvyn Richter. The Politcal Theory of Montesquieu. USA, New-York, Cambridge University Press, 1977. -P.79. 